\title{
De effectiviteit van interventies ter stimulering van bewegen
}

\author{
K.I. Proper • B. Bergstra • I. Bakker • W. van Mechelen
}

Samenvatting Dit artikel is het eerste van een reeks van vier artikelen waarin een overzicht wordt gegeven van de beschikbaarheid en effectiviteit van primaire preventieeerstelijnsleefstijlinterventies die toepasbaar zijn in de bedrijfsgezondheidszorg. Dit artikel gaat in op het leefstijlthema 'bewegen'. Op basis van literatuuronderzoek is geconcludeerd dat bewegingsstimuleringsinterventies een positief effect hebben op een aantal gezondheidsgerelateerde variabelen, zoals de mate van lichamelijke activiteit, het aëroob uithoudingsvermogen en het percentage lichaamsvet. Indien het programma tevens gericht is op het bewegingsapparaat, leidt het over het algemeen tot een vermindering van klachten aan het bewegingsapparaat. Voor het effect op werkgerelateerde variabelen, zoals bijvoorbeeld ziekteverzuim, ontbreekt een bewijs mede vanwege gebrek aan onderzoeken met een goede onderzoeksopzet. Op basis van gesprekken met veldpartijen bleek dat interventies ter stimulering van bewegen weliswaar ontwikkeld en ingezet worden, maar dat deze niet structureel geëvalueerd worden. Arbodiensten zetten bewegen niet of nauwelijks in ten behoeve van primaire preventie. Bij het realiseren van de intentie van de NVAB om leefstijlinterventies vaker in te laten zetten door de bedrijfsarts, dient dit beleidsdoel dan ook goed gecommuniceerd te worden met bedrijfsartsen. Op basis van het thans nieuwe inzicht is het mogelijk dat er richtlijnen ontwikkeld worden voor diverse typen van

K.I. Proper $(\bowtie)$

Dr. Karin Proper, VU medisch centrum, Afdeling Sociale Geneeskunde, EMGO Instituut, Amsterdam; Body@Work, onderzoekscentrum Bewegen, Arbeid en Gezondheid, TNOVUmc, VU medisch centrum, Amsterdam.

CorrespondentieadresDr. Karin I. Proper, VU medisch centrum, Afdeling Sociale Geneeskunde, EMGO Instituut, Van der Boechorststraat 7,1081 BT Amsterdam.

E-mail:ki.proper@vumc.nl. interventies ter stimulering van bewegen, die haalbaar zijn voor toepassing in de werksetting.

Keywords literatuuroverzicht - effectiviteit . interventies . bewegen bedrijfsgezondheidszorg . primaire preventie

Het bewijs dat bewegen goed is voor de gezondheid is reeds geleverd. Diverse epidemiologische onderzoeken hebben de gezondheidseffecten van bewegen onderzocht en een overtuigend, gunstig verband aangetoond tussen bewegen en gezondheid.1-3 Desondanks beweegt de meerderheid van de Nederlandse bevolking nog steeds onvoldoende. Recente cijfers hebben laten zien dat in 2003 48\% van de Nederlandse volwassenen niet voldoet aan de vastgestelde richtlijn voor bewegen, de Nederlandse Norm Gezond Bewegen.4 Deze norm stelt dat voor het behalen van gezondheidswinst iedere volwassene minimaal 30 minuten matig intensief actief moet zijn op ten minste 5 dagen per week. 5 Het bevorderen van meer lichaamsbeweging is daarom van evident belang.

Het ministerie van Volksgezondheid, Welzijn en Sport (VWS) heeft in de nota Langer Gezond Leven onder meer overgewicht en diabetes als speerpunten benoemd voor haar beleid voor de komende jaren. Meer bewegen is voor beide aandoeningen van belang en wordt door VWS dan ook als doelstelling genoemd. Daarbij worden werkgevers nadrukkelijk aangesproken op hun verantwoordelijkheid.6 Ook in de nota Sport, Bewegen en Gezondheid van VWS wordt het bevorderen van meer lichaamsbeweging als beleidsdoelstelling neergelegd en wordt de werkomgeving genoemd als één van de mogelijke settings om beweeginterventies uit te voeren.7 Een groot deel van de volwassen bevolking kan immers via 
het werk bereikt worden en ook voor werkgevers zijn gezonde werknemers van belang. Zo zijn er inmiddels duidelijke aanwijzingen dat sportende werknemers minder verzuimen. 8 Bedrijfsartsen kunnen bij het bevorderen van een gezonde leefstijl, c.q. meer bewegen, een grotere rol spelen dan tot nu toe het geval is geweest. Onduidelijk is echter welke interventies effectief en toepasbaar zijn in de bedrijfsgezondheidszorg. Dit artikel geeft daarop antwoord.

\section{Vraagstelling}

De specifieke vraagsteling van het onderzoek was: wat is bekend over de (kosten-)effectiviteit van eerstelijnsinterventies ter stimulering van bewegen op gezondheids- en werkgerelateerde uitkomstmaten?

\section{Methode}

1 Literatuuronderzoek

\section{Zoekstrategie}

In diverse databases is gezocht naar relevante literatuur, te weten Medline (via PubMed), Picarta, OSH-Rom, PsycInfo en HighWire. De gevonden publicaties zijn aangevuld met literatuur uit de persoonlijke databestanden van de auteurs. Voor de uiteindelijke selectie van literatuur is een aantal criteria opgesteld. De gehanteerde in- en exclusiecriteria staan vermeld in box 1 .

Box 1 Gehanteerde in- en exclusiecriteria Onderzoeken moesten aan de volgende inclusiecriteria voldoen:

1. Datum van publicatie tussen 1 januari 1984 en 1 maart 2004.

2. Het artikel is geschreven in het Nederlands of Engels.

3. Gehanteerde zoektermen betroffen: physical activity, exercise, (intervention or program*), (effect* or evaluate*), (worksite or workplace), adulthood.

4. De interventie is gericht op het stimuleren van meer bewegen.

5. De interventie is gericht op primaire preventie; de onderzoeksgroep bestaat uit een gezonde populatie, d.w.z. geen gezondheidsklachten op basis waarvan zij gestimuleerd worden meer te bewegen.

6. De interventie is ontwikkeld voor de eerste lijn en toepasbaar in de bedrijfsgezondheidszorg.

7. Het onderzoek heeft een (gerandomiseerde) gecontroleerde opzet.
8. Het effect van de interventie wordt geëvalueerd d. m.v. een voor- en ten minste één nameting.

9. Leeftijdscategorie 16-65 jaar (werkende populatie).

10. Uitkomstmaat is gedrags-, gezondheids- of werkgerelateerd, bijvoorbeeld: hoeveelheid beweging, bloeddruk, cholesterol, lichaamsgewicht, of ervaren gezondheid, ziekteverzuim, productiviteit, werktevredenheid of ervaren werkstress.

Onderzoeken zijn op basis van de volgende exclusiecriteria verwijderd:

1. Observationele onderzoeken.

2. De interventie is gericht op secundaire of tertiaire preventie. Bijvoorbeeld als de interventie gericht is op het bestrijden van een reeds aanwezige ziekte d.m.v. stimulering van bewegen.

3. De doelgroep bestaat uit mensen met klachten aan het bewegingsapparaat of andersoortige gezondheidsklachten.

4. De doelgroep bestaat uit jeugd (0-16 jaar) of ouderen $(65+)$.

\section{Inventarisatie veldpartijen}

Er zijn gesprekken gehouden met contactpersonen van NOC*NSF Breedtesport, het Nederlands Instituut voor Sport en Bewegen (NISB), het Nationaal Instituut voor Gezondheidsbevordering en Ziektepreventie (GBW/ NIGZ) en de Nederlandse Hartstichting (NHS). Deze instanties zijn actief op het gebied van bewegen en ondersteunen c.q. ontwikkelen programma's ter stimulering van -bewegen. Daarnaast is gesproken met vertegenwoordigers van een drietal arbodiensten, te weten: ArboNed, KLM Arboservices en de Nederlandse Spoorwegen (maakt gebruikt van de diensten van ArboUnie). Het doel van de gesprekken was het in kaart brengen van de interventies die door deze partijen ontwikkeld, ingezet en geëvalueerd zijn.

\section{Resultaten}

\section{Literatuuronderzoek}

De literatuurzoektocht leverde na eerste selectie 130 publicaties op. Bij lezing bleek dat sommige artikelen toch niet aan de inclusiecriteria voldeden, en werden om die reden alsnog uitgesloten. Uiteindelijk leverde dit 84 artikelen op die 70 onderzoeken behandelden. Gezien de beschikbaarheid van voldoende RCT's is bij de beschrijving van de effectiviteit van interventies uitsluitend gebruikgemaakt van RCT's. 
Gedetailleerde informatie over de onderzoeken en de onderzochte interventies staat beschreven in tabelvorm in het Body@Work-rapport (http://www. bodyatwork.nl/files/rapport_bravo.pdf). 9

1. Werknemers die regelmatig bewegen, zijn gezonder en verzuimen minder, maar leidt een bewegingsprogramma ook tot deze gunstige effecten?

2. Welke interventies ter stimulering van bewegen die toepasbaar zijn door de bedrijfsarts, zijn effectief?

\section{Type interventies}

Wat betreft type interventie waren er twee hoofdgroepen te onderscheiden: interventies waarbij een concreet bewegings- of fitnessprogramma werd aangeboden en interventies die zich richtten op voorlichting of advies. Combinaties van beide kwamen ook voor. De interventies waren individueel of in groepsverband georganiseerd en veelal gericht op het verbeteren van de conditie; dit vaak gecombineerd met spierversterkende oefeningen. Voorlichting en advies was er in verschillende vormen. Vaak was dit advies gebaseerd op een theorie voor gedragsverandering, zoals het transtheoretisch model (TTM) (zie inleiding 'Verandering naar gezond gedrag, hoe doen we dat?'). De meeste onderzoeken waren alleen gericht op het stimuleren van beweging; een gering aantal was ook gericht op andere leefstijlfactoren zoals voeding, roken of alcohol.

\section{Effect op lichamelijke activiteit}

Er zijn 26 RCT's (35 publicaties) gevonden die het effect op lichamelijke activiteit hebben onderzocht.10-44 In deze onderzoeken werden vaak effecten op meer dan één lichamelijke activiteit uitkomstmaat beschreven. Effecten zijn bijvoorbeeld gemeten in termen van energieverbruik, hoeveelheid beweging in de vrije tijd of op het werk, percentage deelnemers dat voldoende of regelmatig beweegt, totaal aantal minuten beweging per dag/ week of het aantal stappen per dag (gemeten met stappenteller). Zowel de duur van de interventie als de momenten waarop de interventie geëvalueerd werd, verschilde behoorlijk tussen de onderzoeken. Zo varieerden de meetmomenten tussen de zes weken16 en zes jaar.11,12 Slechts enkele onderzoeken hadden meerdere langetermijnmetingen uitgevoerd, zodat nagegaan kon worden of eventuele kortetermijneffecten na verloop van tijd wegebden. Vanwege de verschillende resultaten kon dit echter niet bevestigd of ontkracht worden. Immers, sommige onderzoeken vonden een effect op zowel korte termijn (bijvoorbeeld halverwege de interventie of direct na afloop van de interventie) als op de langere termijn, 18,35,36 terwijl andere onderzoeken geen effect vonden op korte of lange termijn.11,12,23,37-40, 42 Geen enkel onderzoek vond een gunstig effect op de langere termijn bij afwezigheid van een effect op de korte termijn. Van de 53 effecten lieten vijftien $(28 \%)$ een significant positief effect zien.13-16,18-21,26,33,35,36 Bij twintig van de $53(38 \%)$ was er wel een positieve trend in de mate van lichamelijke activiteit in het voordeel van de interventiegroep, maar was deze niet significant10,16-18,22,26-28,30-32,34-36,41,42 Bij zestien $(30 \%)$ was geen trend of effect te zien, oftewel: de interventie- en controlegroep veranderden niet of in gelijke mate.11,12,19-25,28,29,37-40,42,44 Verder was bij één van deze onderzoeken37-40 na zes maanden een negatief effect gevonden op het energieverbruik, waarbij de groep die gestructureerde fitness kreeg, meer energie verbruikt had dan de groep die het advies kreeg om meer beweging te integreren in het dagelijkse leven. Na twee jaar was dit effect verdwenen. Tot slot was er nog één onderzoek43 dat een negatieve trend liet zien, waarbij de controlegroep actiever was geworden dan de interventiegroep die een accelerometer als aanvullende interventie had gekregen naast het eenmalige voorlichtingsprogramma.

Over het algemeen lijkt het er dus op dat primair preventieve interventies ter stimulering van bewegen leiden tot meer bewegen. Bij een vergelijking tussen effectieve en niet-effectieve interventies waren veel overeenkomsten te zien. Opvallend was dat tweederde van de effectieve interventies in de werksetting was uitgevoerd, terwijl het merendeel van de niet-effectieve interventies in een andere setting plaatsvond, zoals de eerstelijnsgezondheidszorg. Een voorzichtige conclusie is dan ook dat het erop lijkt dat juist bedrijfsbewegingsprogramma's effectief zijn op lichamelijke activiteit.

\section{Effect op gezondheidsgerelateerde variabelen}

Effecten op de lichaamssamenstelling zijn gemeten in elf RCT's.11,12,17,19-21,30-33,37-40,45,52,53,56 Voor het percentage lichaamsvet werd drie keer een significant positief effect gevonden,19-21,45,53 één keer een positieve trend37-40 en drie keer geen effect.37-40,52,56 Bij de BMI is in geen enkel onderzoek een effect gevonden.11,12,17,19-21,30-33

Het effect op aëroob uithoudingsvermogen is in de meeste onderzoeken bepaald aan de hand van objectieve uitkomstmaten zoals de $V \mathrm{O} 2 \max$, gemeten met behulp van inspanningstesten. Van de elf RCT's hadden er zeven een significant positief effect gevonden.1921,45,49,50,52,55,56 Bij drie onderzoeken was een positieve trend24,25,34,53 aanwezig en één onderzoek11,12 vond geen effect op het aëroob uithoudingsvermogen (fitheidsindex). 
Voor bloeddruk zijn uitkomsten gemeten in zeven RCT's.19-21,30-34,37-40,49 Geen enkel onderzoek vond een significant positief effect. De ene helft van de onderzoeken vond een positieve trend,30-33, 37-40 de andere helft vond echter geen (noemenswaardige) verschillen tussen de onderzoeksgroepen op diastolische en/of systolische bloeddruk.19-21, 30,31,34,37-40,49

Serum cholesterol is gemeten in acht RCT's.1921,30,31,33,34,37-40,49,52,55 Hierbij is één keer een significant positief effect19-21 gevonden, één keer een positieve trend52 en zeven onderzoeken vonden geen effect.30,31,33,34,37-40,49,52,55

Uitkomsten op spierkracht en lenigheid zijn gemeten in vier RCT's.11,12,17,53,56 Twee onderzoeken vonden een significant positief effect op spierkracht,53,56 waarvan één onderzoek53 wel een positief effect vond op buikspierkracht, maar geen effect op armspierkracht. Bovendien vond één onderzoek11,12 een positieve trend op spierkracht. Voor lenigheid toonde één onderzoek een significant positief effect17 en één een lichte positieve trend.53 Onder de noemer algemene gezondheid zijn uitkomsten als welbevinden, zelfgerapporteerde klachten aan het bewegingsapparaat en ervaren gezondheid gerekend. Deze uitkomsten zijn gemeten in acht RCT's met elf effectmaten.11,12,19-21,33,46-51,54

Daarvan hadden er zeven betrekking op klachten aan het bewegingsapparaat, waaronder vooral rugklachten en klachten aan de bovenste extremiteiten (nek- en schouderklachten).11, 12,19-21,49,51 De resultaten van die onderzoeken lieten ofwel een significant gunstig effect zien ofwel een positieve trend (niet significant) op klachten aan het bewegingsapparaat. De resultaten op overige indices voor algemene gezondheid waren niet consistent, zodat over de effectiviteit op deze indices geen eenduidige conclusie kan worden getrokken.

\section{Effect op werkgerelateerde variabelen}

In negen RCT's (17 publicaties)11,12,19-21,37-40,4550,54,57 zijn werkgerelateerde uitkomstmaten onderzocht. Alle onderzoeken betroffen een evaluatie van een beweeginterventie in de bedrijfssetting ('bedrijfsbewegingsprogramma'). De gevonden effecten zijn te rangschikken in de volgende categorieën: arbeidstevredenheid, werkstress, productiviteit, functioneren op het werk ('work ability') en ziekteverzuim. Voor alle uitkomstmaten gold dat er slechts een beperkt aantal beschikbare onderzoeken was, die bovendien inconsistente resultaten lieten zien. Ziekteverzuim was het meest onderzocht, namelijk in vijf onderzoeken.19-21,4648,50,54,57 Daarbij rapporteerden drie onderzoeken geen effect,46-48,54,56 één onderzoek vond een positief effect50 en één vond een positieve trend.19-21

\section{Kosten-effectiviteit}

In slechts twee onderzoeken is de verhouding tussen de kosten en effecten onderzocht.19-21,37-40 Proper et al.19-21 voerden zowel een kosten-batenanalyse als een kosteneffectiviteitanalyse uit van een individueel counseling programma. Zij vonden een gunstige kosten-batenverhouding: in het jaar na afloop van de interventie waren de baten als gevolg van de daling in het ziekteverzuim in de interventiegroep ten opzichte van de controlegroep groter ( $€ 635)$ dan de aanvankelijke kosten van de counseling interventie (€430). Echter, zoals gebruikelijk bij kosten-baten- en kosten-effectiviteitanalyses is de onderzoekspower voor dergelijke scheefverdeelde (kosten)data te laag en was het verschil in baten en kosten niet statistisch significant. De kosten-effectiviteitanalyses lieten positieve ratio's zien, waarbij de interventie weliswaar iets duurder was dan de controleconditie maar wel effectiever op de mate van lichamelijke activiteit, conditie en klachten aan het bewegingsapparaat. Dunn et al.3740 concludeerden grotere verbetering in energieverbruik en bloeddruk tegen lagere kosten.

\section{Inventarisatie veldpartijen}

De geconsulteerde instanties houden zich hoofdzakelijk bezig met de ontwikkeling en implementatie van interventies. Evaluaties van de door hen ingezette interventies vinden niet structureel plaats. Uit een niet-gecontroleerde pilot werd geconcludeerd dat bedrijfssport, een project van $\mathrm{NOC}^{*} \mathrm{NSF}$, een gunstig effect had op de werktevredenheid en mede bijdraagt aan een gezonde leefstijl.58 De huisstijl van het NISB is het 'werkende weg ontwikkelen', waarbij gaandeweg van de praktijk geleerd wordt en waarbij deze leerervaring ingezet wordt voor het vervolgtraject. Er zal voor het Community Based Interventions (CBI)-project een effect- en een procesevaluatie plaatsvinden, waarbij onder meer effecten op individueel niveau ten aanzien van de determinanten van bewegen (kennis, houding en eigen effectiviteit) en veranderingen in het beweeggedrag geëvalueerd worden. De FL@SH-campagne (www.flash123.nl), waarin NISB trekker is, maar ook NIGZ en NOC*NSF participeren, wordt zowel tussentijds als aan het eind geëvalueerd op procesmatige aspecten en op de effecten van de campagne op de gedragsverandering met betrekking tot bewegen, voor zover dit mogelijk is met een voor- en nadesign. Het 7-stap-penplan van het NIGZ is gebaseerd op wetenschappelijk onderzoek. Uit ervaring wordt geconcludeerd dat het 7-stappenplan werkt op zowel gezondheids- als werkgerelateerde variabelen. Ook zou de bekendheid van het 7-stappenplan zijn toegenomen. Uit de gesprekken met de arbodiensten bleek dat het 
stimuleren van bewegen geen primaire aandacht heeft. Bij de ene arbodienst komt het bijvoorbeeld alleen zijdelings voor in de aanpak voor RSI-preventie en in het PAGO. Bij de andere arbodienst wordt bewegen al wel langer ingezet voor reïntegratie. De geconsulteerde arbodiensten zijn van mening dat voorlichting over gezond bewegen geen effect zal hebben wanneer deze niet geïntegreerd is in een cascade van maatregelen. Derhalve wordt nu slechts incidentele aandacht aan bewegen besteed en op basis van klantwensen wordt ad hoc invulling gegeven. ArboNed geeft aan zich actief in te zetten met de ontwikkeling van gezondheidsprogramma's.

\section{Discussie}

Vergelijking met andere reviews

Onze conclusie dat interventies gericht op het stimuleren van bewegen over het algemeen effectief zijn en leiden tot een toename van de lichamelijke activiteit wordt ondersteund door de reviews die in het verleden zijn gepubliceerd: twaalf van de veertien reeds beschikbare reviews rapporteerden positieve resultaten.59-72 De meeste reviews concludeerden dat er kleine positieve effecten zijn op het bevorderen van lichaamsbeweging. Twee van de reviews spraken zich iets krachtiger uit.61,62 In de review van Proper et al. (2003) werd een significant positief effect gevonden bij vijf van de acht onderzochte onderzoeken, waarbij twee RCT's van goede kwaliteit waren.61 Het ging in deze review specifiek om bewegingsstimuleringsinterventies via de werk-setting. Simons-Morton et al. (1998) onderzochten onderzoeken in de eerstelijnsgezondheidszorg en zagen bij vijf van de zeven RCT's een significante toename van de hoeveelheid lichaamsbeweging. 62

Ook werden de gunstige effecten van bewegingsstimuleringsinterventies op het percentage lichaamsvet, het aëroob uithoudingsvermogen, en spierkracht en lenigheid in meerdere of mindere mate bevestigd door de reeds uitgevoerde reviews.59,60,65,71,73 Van deze uitkomsten werd in de reviews een gemengd, maar overwegend positief beeld gegeven. Anders lag dat voor bloeddruk, BMI en serum cholesterol. In onderhavige review werd geconstateerd dat bewegingsinterventies niet effectief zijn op deze uitkomsten. De gevonden reviews daarentegen gaven hierover een gematigd positief beeld. Mogelijk komt dit doordat de onderzoeken voor deze review expliciet geselecteerd zijn op een gezonde populatie. Bij deelnemers met een normaal gewicht, normale bloeddruk en normaal cholesterolgehalte valt immers minder winst te behalen. Tot slot worden onze conclusies over de effectiviteit van bedrijfsbewegingsprogramma's ondersteund door de review van Proper et al.,74 de enige review waarin werkgerelateerde uitkomsten werden beschreven. Zij constateerden dat er geen bewijs was voor een positief effect op werktevredenheid, productiviteit en stress, en, mede als gevolg van een gebrek aan gedegen onderzoeken, beperkt bewijs voor een positief effect op ziekteverzuim. Dit gebrek aan bewijs heeft vooral te maken met het feit dat er zeer weinig onderzoeken zijn verricht die het effect op deze bedrijfsrelevante uitkomstmaten hebben onderzocht, maar nog belangrijker: die deze uitkomstmaten als primaire uitkomstmaat hebben opgenomen. Daardoor is de 'power' van de betreffende onderzoeken vaak te laag, als gevolg waarvan het vinden van statistisch significante resultaten bemoeilijkt wordt. Daarnaast hebben de meeste onderzoeken een (te) korte termijn gehanteerd voor een gedegen evaluatie op deze uitkomstmaten. Verwacht mag namelijk worden dat in eerste instantie effecten op lichamelijke activiteit optreden, welke vervolgens zullen leiden tot een effect op de lichamelijke conditie en de gezondheid, om uiteindelijk effecten te kunnen sorteren op werkgerelateerde variabelen zoals ziekteverzuim. Meer (langetermijn)onderzoek naar het effect van (bedrijfs)bewegingsprogramma's op deze uitkomstmaten is dan ook zeer wenselijk. Ook over de kosten-effectiviteitverhouding, of liever de kosten-batenverhouding ontbreekt het nodige bewijs. Gezien de aanzienlijke gezondheidszorgkosten en indirecte kosten (bijvoorbeeld als gevolg van ziekteverzuim en productiviteitsverlies) van inactiviteit en overgewicht 75,76 is stimulering van bewegen dan ook van groot belang voor de overheid en het bedrijf.

\section{Toepasbaarheid interventies voor bedrijfsartsen}

De onderzochte interventies zijn in principe goed toepasbaar door en voor bedrijfsartsen. Op de vraag wat nu (potentieel) de meest effectieve interventie is, en welke aan te bevelen is voor toepassing in de bedrijfsgezondheidszorg, is niet eenvoudig een antwoord te geven. Uit onze overzichten was namelijk geen patroon te constateren omtrent de inhoud van de interventie en het effect. Hieronder zullen dan ook suggesties worden gedaan voor potentieel effectieve interventies die eenvoudig en zonder al te hoge kosten in de bedrijfsgezondheidszorg toegepast kunnen worden. Persoonlijke voorlichting en advisering, bij voorkeur gebaseerd op het huidige beweeggedrag en de motivatie van de persoon, is veelal effectief. Hierbij kan gebruikgemaakt worden van bestaand schriftelijk of audiovisueel materiaal. Schriftelijk materiaal kan desgewenst bedrijfsbreed verspreid worden, bijvoorbeeld als bijlage bij een personeelsblad. Het vertonen van audiovisueel materiaal zou gekoppeld kunnen worden aan 
reguliere werkoverleggen of andere informatieve bijeenkomsten. Ook persoonlijke adviezen en consulten zijn goed mogelijk in een werksetting. Te denken valt aan inloopspreekuren en jaarlijkse check-ups met eventuele vervolgconsulten. Een soort 'beweegrecept', een methode die in de huisartspraktijk nogal eens wordt toegepast en effectief is gebleken, kan ook eenvoudig door een bedrijfsarts worden gegeven. Daarnaast is het internet een veelbelovend medium en bovendien bij bedrijven (met kantoorwerknemers) eenvoudig te realiseren. Op deze manier wordt een grote groep bereikt met relatief weinig kosten. Naast deze meer persoonlijke, individueel gerichte strategieën voor gedragsverandering, zijn er diverse mogelijkheden voor het aanbieden van concrete bewegingsprogramma's. Te denken valt bijvoorbeeld aan de diverse fitnessprogramma's, in huis (in-company) of bij de 'sportschool om de hoek', of het stimuleren van actief woon-werkverkeer, hetgeen een doeltreffende manier is om beweging te integreren in het dagelijks (werk)leven. Hiervoor kunnen allerlei voorwaardenscheppende maatregelen genomen worden, zoals het zorgen voor goede fietsenstallingen en douches. Ook bestaat er nog steeds een aantrekkelijke fiscale regeling voor een fiets-van-de-zaak. Veranderingen in de omgeving zijn eveneens veelbelovende interventies.77,78 Dergelijke veranderingen zijn gericht op het wegnemen van de barrières of het stimuleren van het nemen van de gezonde keuze. Ter stimulering van bewegen valt te denken aan het stimuleren van het nemen van de trap, waarbij het trappenhuis aantrekkelijk en goed zichtbaar wordt gemaakt en de lift in een verre, donkere hoek van het gebouw wordt geplaatst.

De gunstige effecten van bewegingsstimuleringsinterventies worden alleen behouden als er structureel aan deelgenomen wordt, bij voorkeur als onderdeel van het dagelijkse leefpatroon. Geadviseerd wordt dan ook werknemers structureel en blijvend te betrekken bij het creëren van mogelijkheden en aandacht te schenken aan deelname en uitval. Ook is het van belang om realistisch te zijn in de verwachtingen. Bovengenoemde impliceert dat de deskundigheid en kwaliteiten van de bedrijfsarts van belang zijn bij het uitvoeren van een interventie. Naast de benodigde kennis over de verschillende vormen van interventies, is het bijvoorbeeld van belang dat de bedrijfsarts in staat is de werknemer (blijvend) te motiveren tot gedragsverandering. Voor huisartsen is het blad Arts in beweging uitgebracht. Dit blad heeft als doelstellingen:

1. huisartsen bijscholen op het gebied van sport en bewegen en informatie aanreiken aan (inactieve) patiënten, en

2. huisartsen aansporen zelf meer te bewegen.
In het kader van een goede leefstijladvisering ter bestrijding van inactiviteit en bevordering van de gezondheid zou een dergelijk laagdrempelig en praktijkgericht blad tevens voor bedrijfsartsen uitgebracht kunnen worden.

Het bewijs over de effectiviteit op werkgerelateerde uitkomstmaten is vooralsnog beperkt. Oorzaken hiervan zijn onder meer het gegeven dat dergelijke effecten pas op de lange termijn te bewerkstelligen zijn. Dit houdt dan tevens in dat de interventie geen tijdelijk karakter, maar een continu karakter moet hebben en een vast onderdeel vormt van het arbo- of gezondheidsbeleid binnen het bedrijf, waar de werknemers aan kunnen, maar vooral aan blijven deelnemen. Effecten op ziekteverzuim(kosten), een belangrijke maat voor het bedrijf, zijn dan mogelijk te realiseren.

\section{Conclusies}

Interventies ter stimulering van bewegen zijn over het algemeen effectief en leiden tot een toename van de lichamelijke activiteit. Bovendien lijken vooral bedrijfsbewegingsprogramma's effectief te zijn op deze uitkomstmaat. Het is echter onbekend in welke mate effecten beklijven dan wel wegebben. Interventies ter stimulering van bewegen hebben een gunstig effect op percentage lichaamsvet, conditie, en spierkracht en lenigheid. Daarentegen zijn beweeginterventies niet effectief gebleken op BMI, bloeddruk en cholesterol. Fitnessprogramma's waarin gericht en gerelateerd aan het soort werk aandacht wordt besteed aan het bewegingsapparaat, zijn effectief gebleken op klachten aan het bewegingsapparaat. De effectiviteit van (bedrijfs)bewegingsprogramma's op werkgerelateerde uitkomsten is vooralsnog niet afdoende aangetoond. Als gevolg van een beperkt aantal onderzoeken of inconsistente resultaten onder de onderzoeken konden geen eenduidige conclusies getrokken worden. Mogelijk zijn bedrijfsfitnessprogramma's met een permanent karakter wel effectief op ziekteverzuim.

Er is weinig onderzoek gedaan naar de kosteneffectiviteit van bewegingsinterventies. De indruk is positief, in die zin dat de effecten (of baten) de investeringen op redelijk korte termijn overschrijden.

Belangenconflicten: geen gemeld.

Financiële ondersteuning: ministerie van VWS.

\section{Literatuur}

U.S. Department of Health and Human Services. Physical activity and health: a report of the Surgeon General. Atlanta(GA): U. S. Department of Health and Human Services, Centers for 
Disease Control and Prevention, National Center for Chronic Disease Prevention and Health Promotion, 1996.

Maas IAM, Gijsen R, Lobbezoo IE, Poos MJJC (red). Volksgezondheid Toekomst Verkenning 1997; De gezondheidstoestand: een actualisering. Maarssen: Elsevier/De Tijdstroom, 1997.

Department of Health, Physical Activity, Health Improvement and Prevention. At least five a week. Londen: Department of Health, 2004.

Ooijendijk WTM, Hildebrandt VH, Stiggelbout M. Bewegen in Nederland. In: Hildebrandt VH, Ooijendijk WTM, Stiggelbout M, et al. (red). Trendrapport Bewegen en Gezondheid 2002/2003. Amsterdam: PlantijnCasparie, 2004: 25-50.

Kemper HCG, Ooijendijk WTM, Stiggelbout M. Consensus over de Nederlandse norm voor gezond bewegen. TSG 2000; 78: 180-183.

Ministerie van VWS. Langer gezond leven: ook een kwestie van gezond gedrag. Den Haag: Ministerie van VWS, 2003.

Ministerie van VWS. Sport, bewegen en gezondheid. Naar een actief kabinetsbeleid ter vergroting van de gezondheid door en bij sport en beweging. Den Haag: Ministerie van VWS, 2001.

Heuvel SG van den, Boshuizen HC, Hildebrandt VH, et al. Sporten, type werk, arbeidsverzuim en welbevinden : resultaten van een 3-jarige follow-up studie. TSG 2003; 5: 256-264.

Proper KI, Bakker I, Overbeek K van, et al. Naar een gericht BRAVO-beleid door bedrijfsartsen. Body@Work rapport, april 2005.

Marcus BH, Emmons KM, Simkin-Silverman LR, et al. Evaluation of motivationally tailored vs standard self-help physical activity interventions at the workplace. Am J Health Promot 1998; 12: 246-253

Perkiö-Mäkelä M. Influence of exercise-focused group activities on the physical activity, functional capacity and work ability of female farmers - a three year follow up. Int J Occup Safety Ergonomics 1999; 5: 381-394.

Perkiö-Mäkelä M. Exercise and ergonomics-focused group counseling among female farmers. Occup Ergonomics 2001; 2: 239-250.

Emmons KM, Linnan LA, Shadel WG, et al. The Working healthy project: a worksite health promotion trial targeting physical activity, diet and smoking. J Occup Environ Med 1999; 41: 545-555.

Peterson TR, Aldana SG. Improving exercise behavior: an application of the Stages of Change model in a worksite setting. Am J Health Promot 1999; 13: 229-232.

Speck BJ, Looney SW. Effects of minimal intervention to increase physical activity in women. Nurs Res 2001; 50: 374-378.

Hager RL, Hardy A, Aldana SG, et al. Evaluation of an internet stage-based physical activity intervention. Am J Health Educ 2002; 33: 329-335.

Campbell MK, Tessaro I, DeVellis B, et al. Effects of a tailored health promotion program for female blue-collar workers: Health works for women. Prev Med 2002; 34: 313-323.

Napolitano MA, Fotheringham M, Tate D, et al. Evaluation of an internet-based physical activity intervention: a preliminary investigation. Ann Behav Med 2003; 25: 92-99.

Proper KI, Hildebrandt VH, Beek AJ van der, et al. Effect of individual counseling om physical activity, fitness and health. Am J Prev Med 2003; 24: 218-226.

Proper KI, Beek AJ van der, Hildebrandt VH, et al. Worksite health promotion using individual counseling and the effectiveness on sick leaves. Results of a randomised controlled trial. Occup Environ Med 2004; 61: 275-279.

Proper KI, Bruyne M, Hildebrandt VH, et al. Cost-benefit and cost-effectiveness analysis of a worksite physical activity counseling program. Scand J Work Environ Health 2004; 30: 36-46.

Marshall AL, Leslie ER, Bauman AE, et al. Print versus website physical activity programs. Am J Prev Med 2003; 25: 88-94.
Aittasalo M, Miilunpalo S, Suni J. The effectiveness of physical activity counseling in a worksite setting: a randomized, controlled trial. Patient Educ Couns 2004, 55: 193-202.

King AC, Sallis JF, Dunn AL, et al. Overview of the Activity Counseling Trial (ACT) intervention for promoting physical activity in primary health care settings. Med Sci Sports Exerc 1998; 30: 1086-1096.

Simons-Morton DG, Blair SN, King AC, et al. Effects of physical activity counseling in primary care; the Activity Counseling trial: a randomized controlled trial. JAMA 2001; 286: 677-687.

Stevens S, Hillsdon M, Thorogood M, et al. Cost-effectiveness of a primary care based physical activity intervention in 45-74 year old men and women: a randomised controlled trial. Br J Sports Med 1998; 32: 236-241.

Harland J, White M, Drinkwater C, et al. The Newcastle exercise project: a randomised controlled trial of methods to promote physical activity in primary care. BMJ 1999; 319: 828-832.

Bull FC, Kreuter MW, Scharff DP. Effects of tailored, personalized and general health messages on physical activity. Patient Educ Couns 1999; 36: 181-192.

Norris SL, Grothaus LC, Buchner DM, et al. Effectiveness of physician-based assessment and counseling for exercise in a staff model HMO. Prev Med 2000; 30: 513-523.

Steptoe A, Doherty S, Rink E, et al. Behavioural counselling in general practice for the promotion of healthy behaviour among adults at increased risk of coronary heart disease: randomised trial. BMJ 1999; 319: 943-947.

Steptoe A, Kerry S, Rink E, et al. The impact of behavioral counseling on stage of change in fat intake, physical activity and cigarette smoking in adults at increased risk of coronary heart disease. Am J Public Health 2001; 91: 265-269.

Hillsdon M, Thorogood M, White I, et al. Advising people to take more exercise is ineffective: a randomized controlled trial of physical activity promotion in primary care. Int $\mathbf{J}$ Epidemiol 2002; 31: 808-815.

Elley CR, Kerse N, Aroll B, et al. Effectiveness of counselling patients on physical activity in general practice: cluster randomised controlled trial. BMJ 2003; 326: 793.

Little P, Dorward M, Gralton S, et al. A randomised controlled trial of three pragmatic approaches to initiate increased physical activity in sedentary patients with risk factors for cardiovasculair disease. Br J Gen Pract 2004; 54: 189-195.

Marcus BH, Bock BC, Pinto BM, et al. Efficacy of an individualized, motivationally-tailored physical activity intervention. Ann Behav Med 1998; 20: 174-180.

Bock BC, Marcus BH, Pinto BM, et al. Maintenance of physical activity following an individualized motivationally tailored intervention. Ann Behav Med 2001; 23: 79-87.

Dunn AL, Marcus BH, Kamper JB, et al. Reduction in cardiovascular disease risk factor: 6-month results from Project Active. Prev Med 1997; 26: 883-892.

Dunn AL, Marcus BH, Kampert JB, et al. Comparison of lifestyle and structured interventions to increase physical activity and cardiorespiratory fitness. JAMA 1999; 281: 327-334.

Smolander J, Blair SN, Kohl HW. Work ability, physical activity and cardiorespiratory fitness: 2-year results from Project Active. J Occup Environ Med 2000; 42: 906-910.

Sevick MA, Dunn AL, Morrow MS, et al. Cost-effectiveness of Lifestyle and structured interventions in sedentary adults: results of project Active. Am J Prev Med 2000; 19: 1-8.

Marshall AL, Bauman AE, Owen N, et al. Population-based randomized controlled trial of a stage-targeted physical activity intervention. Ann Behav Med 2003; 25: 194-202.

Marshall AL, Bauman AE, Owen N, et al. Reaching out to promote physical activity in Australia: a statewide randomized controlled trial of a stage-targeted intervention. Am J Health Promot 2004; 18: 283-287. 
Cardinal BJ. Effects of behavioral monitoring on physical activity and psychosocial determinants of exercise behavior. Soc Behav Person 1997; 25: 13-18.

Calfas KJ, Sallis JF, Nichols JF, et al. Project GRAD: two-year outcomes of a randomised controlled physical activity intervention among young adults. Am J Prev Med 2002; 18: 28-37.

Oden G, Crouse SP, Reynolds C. Worker productivity, job satisfaction and work-related stress: the influence of an employee fitness program. Fitbus 1989; June: 198-203.

Rosenfeld O, Tenenbaum G, Ruskin H, et al. The effect of physical training on objective and subjective measures of productivity and efficiency in industry. Ergonomics 1989; 32: 1019-1028.

Rosenfeld O, Tenenbaum G, Ruskin H, et al. Behavioural modifications following a physical activity programme in the Israeli pharmaceutical industry. Aust J Sci Med Sport 1990; Dec: 93-96.

Halfon ST, Rosenfeld O, Ruskin H, et al. Daily physical activity program for industrial employees. In: Kaneko M, editor. Fitness for the aged, disabled and industrial worker. Champaign: Human Kinetics 1994: 260-265.

Grønningsæter H, Hytten K, Skauli G, et al. Improved health and coping by physical exercise or cognitive behavioral stress management training in a work environment. Psychol Health 1992; 7: 147-163.

Kerr JH, Vos MCH. Employee fitness programmes, absenteeism and general well-being. Work Stress 1993; 7: 179-190.

Gundewall B, Liljeqvist M, Hansson T. Primary prevention of back symptoms and absence from work. Spine 1998; 18: 587-594.

Grandjean PW, Oden GL, Crouse SF, et al. Lipid and lipoprotein changes in women following 6 months of exercise training in a worksite fitness program. J Sports Med Fitness 1996; 36: 54-59.

Harrell JS, Johnston LF, Griggs ThR, et al. An occupation based physical activity intervention program: improving fitness and decreasing obesity. AAOHN J 1996; 44: 377-384.

Eriksen HR, Ihlebæk C, Mikkelsen A, et al. Improving subjective health at the worksite: a randomized controlled trial of stress management training, physical exercise and an integrated health programme. Occup Med 2002; 52: 383-391.

Oja P, Vuori I, Paronen O. Daily walking and cycling to work: their utility as health-enhancing physical activity. Patient Educ Couns 1998; 33(suppl): S87-S94.

Winett RA, Wojcik JR, Fox LD, et al. Effects of low volume resistance and cardiovasculair training on strenght and aerobic capacity in unfit men and women: a demonstration of a treshold model. J Behav Med 2003; 26: 183-195.

Nurminen E, Malmivaara A, Ilmarinen J, et al. Effectiveness of a worksite exercise program with respect to perceived work ability and sick leaves among women with physical work. Scand J Work Environ Health 2002; 28: 85-93.

Camp M van den, Michels B. Een gezonde werkomgeving door bedrijfssport? Een onderzoek naar de effecten van bedrijfssport. Nijmegen: Hogeschool van Arnhem en Nijmegen, 2004 (Scriptie).

Dishman RK, Oldenburg B, O’Neal H, et al. Worksite physical activity interventions. Am J Prev Med 1998, 15: 344-360.

Janer G, Sala M, Kogevinas M. Health promotion trials at worksites and risk factors for cancer. Scand J Work Environ Health 2002; 28: 141-157.
Proper KI, Koning M, Beek AJ van der, et al. The effectiveness of worksite physical activity programs on physical activity, fitness, and health. Clin J Sport Med 2003; 13: 106-117.

Simons-Morton DG, Calfas KJ, Oldenburg B, et al. Effects of interventions in health care settings on physical activity or cardiorespiratory fitness. Am J Prev Med 1998; 15: 413-430.

Eaton CB, Menard LM. A systematic review of physical activity promotion in primary care office settings. Br J Sports Med 1998; 32: 11-16.

Eakin EG, Glasgow RE, Riley KM. Review of primary-care based physical activity intervention studies. J Fam Pract 2000; 49: 158-168.

Wilcox S, Parra-Medina D, Thompson-Robinson M, et al. Nutrition and physical activity interventions to reduce cardiovasculair disease risk in health care settings: a quantative review with a focus on women. Nutr Rev 2001; 59: 197-215.

Eden KB, Orleans CT, Mulrow CD, et al. Does counseling by clinicians improve physical activity? A summary of the evidence for the US Preventive Services Task Force. Ann Intern Med 2002; 137: 208-215.

Sluijs EMF van, Poppel MNM van, Mechelen W van. Stage-based lifestyle interventions in primary care: are they effective? Am J Prev Med 2004; 26: 330-343.

Hillsdon M, Thorogood M, Anstiss T, et al. Randomised controlled trials of physical activity promotion in free living populations: a review. J Epidemiol Community health 1995; 49: 448-453.

Hillsdon M, Thorogood M. A systematic review of physical activity promotion strategies. Br J Sports Med 1996: 30: 84-89.

Dishman RK, Buckworth J. Increasing physical activity: a quantative synthesis. Med Sci Sports Exerc 1996; 28: 706-718.

Dunn AL, Andersen RE, Jakicic JM. Lifestyle physical activity interventions: history, short- and long-term effects and recommendations. Am J Prev Med 1998; 15: 398-412.

Adams $\mathrm{J}$, White M. Are activity promotion interventions based on the transtheoretical model effective? A critical review. Br J Sports Med 2003; 37: 106-114.

Shepard RJ. Worksite fitness and exercise programs: a review of methodology and health impact. Am J Health Promot 1996; 10: 436-452.

Proper KI, Staal BJ, Hildebrandt VH, et al. Effectiveness of physical activity programs at worksites with respect to workrelated outcomes. Scand J Work Environ Health 2002; 28: 75-84.

Proper KI, Chorus AMJ, Hildebrandt VH. De gezondheidszorgkosten in Nederland als gevolg van onvoldoende lichamelijke activiteit en sportblessures. In: Hildebrandt VH, Ooijendijk WTM, Stiggelbout M, et al (red). Trendrapport Bewegen en Gezondheid 2002/2003. Amsterdam: PlantijnCasparie, 2004: 117-130.

Katzmarzyk PT, Janssen I. The economic costs associated with physical inactivity and obesity in Canada: an update. Can J Appl Physiol 2004; 29: 90-115.

Wetter AC, Goldberg JP, King A, et al. How and why do individual make food and physical activity choices. Nutr Rev 2001; 59 (suppl): S11-S20.

Engbers LH, Poppel MNM van, Chin A Paw MJ, Mechelen W van. Worksite health promotion programs with environmental changes a systematic review. Am J Prev Med. 2005; 29: 61-70. 